\title{
Nitrogen acquisition, storage, and use by the co-occurring Mediterranean seagrasses Cymodocea nodosa and Zostera noltii
}

\author{
George P. Kraemer* ${ }^{*}$ Lucia Mazzella \\ Laboratorio di Ecologia del Benthos, Stazione Zoologica di Napoli, Punta San Pietro, I-80077 Ischia (NA), Italy
}

\begin{abstract}
Shoot density, shoot, root, and rhizome tissue biomass and $N$ content, and $\mathrm{N}$ assimilation by leaf and root tissues of the 2 co-occuring seagrasses Cymodocea nodosa and Zostera noltiu were measured over the course of a year at a central Mediterranean site. Concentrations of dissolved inorganic nitrogen ( $\mathrm{DIN} ; \mathrm{NH}_{4}{ }^{+},\left[\mathrm{NO}_{3}{ }^{-}+\mathrm{NO}_{2}{ }^{-}\right]$) co-varied in the canopy water. Sediment $\mathrm{NH}_{4}{ }^{+}$concentration varied within the top $10 \mathrm{~cm}$ of the sediments, while those of $\left[\mathrm{NO}_{3}{ }^{-}+\mathrm{NO}_{2}{ }^{-}\right]$were virtually invariant. $C$. nodosa and $Z$. noltii appeared to contribute to the replenishment of the sediment DIN reservoir as growth declined and senescence ensued in the fall; the peak in plant-based $N$ preceded the peak of sediment DIN by 1 to 2 mo. C. nodosa had a June peak in glutamine synthetase (GS) activity in leaf tissue, and showed greater variation over the course of the study than did $Z$. noltii, for which there was a February peak in shoot GS activity. The leaves, rhizomes, and roots within each species exhibited different patterns of tissue $\mathrm{N}$ content over the course of the year, indicating different strategies of $\mathrm{N}$ storage and subsequent use. Within a species, assimilated $N$ was first allocated to leaves, then rhizomes and roots. Leaves, in addition to rhizomes, appear to have a $\mathrm{N}$ storage function. $\mathrm{C}$. nodosa maintained high tissue $N$ levels for longer periods than did $Z$. noltii, suggesting that clonal modules of $C$. nodosa were more physiologically integrated than modules of $Z$. noltii. The average potential for $N$ assimilation through $Z$. noltii tissues was estimated to be roughly $43 \%$ of the total for C. nodosa and $Z$. noltii.
\end{abstract}

KEY WORDS: Cymodocea $\cdot$ Zostera $\cdot$ Seagrass $\cdot$ Nitrogen $\cdot$ Glutamine synthetase

\section{INTRODUCTION}

Seagrasses require nitrogen for maintenance and growth. Although levels of dissolved inorganic nitrogen (DIN) in the sediments usually greatly exceed those in the water column, uptake of DIN by seagrass leaves and its assimilation can be more important than root acquisition (Hemminga et al. 1991, Pedersen \& Borum 1992, Hemminga et al. 1994, Kraemer \& Mazzella 1996), even in oligotrophic environments (Stapel \& Hemminga 1997). The availability of DIN in the water column of $\mathrm{N}$-limited, temperate coastal environments generally cycles between winter highs and

\footnotetext{
- Present address: Division of Natural Sciences, SUNY/Purchase College, 735 Anderson Hill Road, Purchase, New York 10577, USA.E-mail: gkraemer@purvid.purchase.edu
}

summer lows (e.g. Scotto di Carlo et al. 1985, Vidondo \& Duarte 1995). Seasonal cycles of DIN abundance in sediment pore waters are less well known (Caffrey 1995).

DIN is assimilated (converted to organic form) by an enzyme system that involves glutamine synthetase (GS). GS facilitates the conversion of $\mathrm{NH}_{4}{ }^{+}$to the amino acid glutamine (Lea 1993). Assimilated $N$ may be used immediately in the production of new tissue, or may be stored if conditions are not conducive to growth (e.g. low light during winter). Seagrasses have a significant $\mathrm{N}$ storage capacity in rhizome and perhaps other tissues. Consequently, temporal patterns of plant $N$ use (i.e. in growth) may not mirror patterns of $N$ availability in the seagrass meadow environment.

Seasonal fluctuations in the $\mathrm{N}$ content of seagrass tissues are known, if incompletely. Many studies report 
concentrations in leaves only (Harrison \& Mann 1975, Alcoverro et al. 1995, 1997), or a employ coarsegrained sampling schedule (e.g. every 3 mo; Pirc \& Wollenweber 1989). The latter study demonstrated February highs and July lows in the $\mathrm{N}$ content of leaves, rhizomes and roots of Cymodocea nodosa (Pirc \& Wollenweber 1989). The highest concentration of $N$ in tissues of Zostera noltii was found in November, followed by a gradual decline to the lowest concentration in August (Pérez-Lloréns \& Niell 1993). Pérez \& Romero (1994) reported a similar pattern in $Z$. noltii tissues, though maximum levels appeared shifted to April or May. Therefore, in addition to interspecific differences in the pattern of $\mathrm{N}$ accumulation, differences may also occur among sites.

Cymodocea nodosa (Ucria) Aschers. and Zostera noltii Hornem. are relatively small, fast-growing, colonizing seagrasses (den Hartog 1970). They co-occur in mixed meadows in the central and northwestern Mediterranean Sea and, therefore, may rely on the same pools of $\mathrm{N}$ to support growth. Variation in the biology of these seagrasses is linked to a certain degree to variation in the physical environment. $C$. nodosa may be less tightly coupled to environmental changes since it possesses a larger commitment to storage tissue; on an annual basis, $C$. nodosa allocates $59 \%$ of total plant biomass rhizome tissue, in comparison to only $36 \%$ by $Z$. noltii (Cancemi 1991, Buia \& Marzocchi 1995, Kraemer unpubl. data). Additionally, clonal modules of $C$. nodosa may be more physiologically integrated than those of $Z$. noltii, rhizome interconnections among shoots of $C$. nodosa are longer lived (Duarte 1991), and tissue at least 11 internodes distal to the growing tip provides energy and materials to support the growth of developing leaf bundles (Terrados et al. 1997).

This 12 mo study compared patterns of $\mathrm{N}$ acquisition, storage, and use by the 2 co-occurring Mediterranean seagrasses Cymodocea nodosa and Zostera noltii. The goal was to investigate the relationships among $N$ assimilation and availability, and accumulation and depletion in leaf, rhizome, and root tissues during growth of 2 seagrasses that likely differ in the degree to which their clonal modules and, consequently, their biology is coupled to the abiotic environment. The pattern of leaf $\mathrm{N}$ assimilation was compared with $\mathrm{N}$ requirements for growth of existing shoots to elucidate strategies for the acquisition, storage, and use of $\mathrm{N}$.

\section{MATERIALS AND METHODS}

Biomass, $\mathrm{N}$ assimilation and tissue $\mathrm{N}$ content. The study was conducted from October 1994 to October 1995 at a site at $5 \mathrm{~m}$ depth in a protected embayment adjacent to the Aragonese castle on the island of Ischia in the Gulf of Naples (Italy). At the study site, Cymodocea nodosa and Zostera noltii were intermixed throughout an irregularly shaped subsection (ca 150 to $200 \mathrm{~m}^{2}$ ) of a larger meadow. For each approximately monthly sample, $C$. nodosa and $Z$. noltii tissues within 3 haphazardly placed, replicate quadrats $\left(400 \mathrm{~cm}^{2}\right)$ were removed to a depth of 10 to $15 \mathrm{~cm}$. In the laboratory, leaf densities of both species within each quadrat were recorded and epiphytes were removed from blades by scraping with a razor blade. Plants were separated into green leaves, roots, and rhizomes (horizontal and vertical pooled), rinsed in fresh water, and dried at $80^{\circ} \mathrm{C}$ for ca $18 \mathrm{~h}$ before weighing. The correlation between tissue biomass within quadrats was examined using Pearson Product-Moment analysis.

Leaf growth rates of both species were measured according to Zieman (1974). Leaf bundles of Cymodocea nodosa ( $\mathrm{n}_{\mathrm{avg}}=16$ for each sample) and Zostera noltii $\left(\mathrm{n}_{\mathrm{avg}}=14\right)$, haphazardly chosen within the meadow, were punched with the tip only 10.1 to $0.2 \mathrm{~mm}$ diameter) of a fine needle. Following $7 \mathrm{~d}$ of growth, leaf bundles were collected. Leaves were examined at $50 \times$ magnification to identify needle perforations. The new tissue produced by each shoot was dried overnight at $80^{\circ} \mathrm{C}$ and weighed.

The rates of $\mathrm{N}$ assimilation in leaf and root tissues were measured using an in vitro assay of GS activity (Pregnall et al. 1987). Five samples of leaf and root tissue for each species were cleaned of epiphytes and sediments, respectively. Total root biomass of individual rhizomes of Zostera noltii was too small to assay from December through March; during this period roots from several rhizomes were pooled. The results of these root assays are presented without measures of variability. Tissues were ground in an ice-cold, irnidazole-based extraction buffer (for details of protocol, see Kraemer et al. 1997). An aliquot of the resulting tissue extract was added to the reaction cocktail containing all reagents for the GS assay defined by Pregnall et al. (1987). Controls were run with extraction buffer substituted for tissue homogenate. Although the in vitro GS assays were conducted at $35^{\circ} \mathrm{C}$, activities were temperature-corrected to ambient water temperature (recorded at the time of collection) using a measured $\mathrm{Q}_{10}$ of 2.1 ( $\mathrm{SD}=0.2$; data not shown).

Biomass from the 3 quadrats was combined by tissue type. Therefore, the $\mathrm{N}$ contents reported here are averages for tissues pooled from 3 quadrats for each sample date. For leaf samples, only green tissue was retained. After drying, samples were ground and sieved, and the portion $<200 \mu \mathrm{m}$ was retained and re-dried $\left(80^{\circ} \mathrm{C}, 4 \mathrm{~h}\right)$ before measurement of $\mathrm{N}$ content using a Carlo Erba CHN analyzer, with an acetonitrile standard. The coef- 
ficient of variation of 3 replicate leaf samples was $1 \%$ while that of roots and rhizomes was 1 to $3 \%$. N required to support measured growth of existing Cymodocea nodosa and Zostera noltii leaves (mg $\mathrm{N}$ $\mathrm{m}^{-2} \mathrm{~d}^{-1}$ ) was estimated by multiplying growth rate (mg DW leaf ${ }^{-1} \mathrm{~d}^{-1}$ ) by $\mathrm{N}$ content ( $\mathrm{mg} \mathrm{N} \mathrm{mg}^{-1} \mathrm{DW}$ ) by shoot density (no. shoots $\mathrm{m}^{-2}$ ). These calculations do not take into account $N$ required for the production of new shoots or subterranean tissue. Optimum rates of $N$ supply (nitrogen assimilatory potential, NAP; $\mathrm{mg} \mathrm{N} \mathrm{m}^{-2}$ $\mathrm{h}^{-1}$ ) were estimated by multiplying GS activity (mg N $\mathrm{g}^{-1} \mathrm{FW} \mathrm{h}^{-1}$ ) by biomass (mg DW $\mathrm{m}^{-2}$ ) by a FW:DW conversion factor. NAP provides useful information in the pattern of values, rather than absolute values. $N$ stocks (mg $\mathrm{N} \mathrm{m}^{-2}$ ) were estimated by multiplying biomass ( $\mathrm{mg} \mathrm{DW} \mathrm{m}^{-2}$ ) by $\mathrm{N}$ content ( $\mathrm{mg} \mathrm{N} \mathrm{mg}^{-1} \mathrm{DW}$ ).

Dissolved inorganic nitrogen. A total of 4 to 7 (usually 5) $3 \mathrm{~cm}$ diameter sediment cores were removed from the top $10 \mathrm{~cm}$ of the sediment-seagrass matrix. Cores were frozen for storage within 1 h of collection. After thawing, the sediment pore water within each core was collected by centrifugation through glass wool ( $3 \mathrm{~min}, 2500 \mathrm{rpm}$ ) and clarified by filtration $(0.45 \mu \mathrm{M})$. Samples were stored at $-80^{\circ} \mathrm{C}$ prior to DIN analysis. Five undiluted water samples, obtained from within the leaf canopy 3 to $5 \mathrm{~cm}$ from the sedimentwater interface, were also collected during each monthly visit to the site. They were centrifuged and filtered as above, and frozen at $-80^{\circ} \mathrm{C}$. Ammonium (Liddicoat et al. 1974) and [nitrate + nitrite] (Jones 1984) were measured in the 0 to $10 \mathrm{~cm}$ integrated samples, using artificial seawater $\left(31 \mathrm{~g} \mathrm{NaCl}, 10 \mathrm{~g} \mathrm{MgSO}_{4}\right.$, $0.05 \mathrm{~g} \mathrm{NaHCO}_{3} \mathrm{l}^{-1}$ distilled water) for blanks and as diluent. The correlation between $\left[\mathrm{NO}_{3}{ }^{-}+\mathrm{NO}_{2}{ }^{-}\right]$and $\mathrm{NH}_{4}{ }^{+}$concentrations within each sample was examined using Pearson Product-Moment analysis.

\section{RESULTS}

\section{$\mathrm{N}$ concentration}

Concentrations of $\mathrm{NH}_{4}{ }^{+}$in the canopy water samples were high in winter, low in summer, and significantly correlated with $\left[\mathrm{NO}_{3}^{-}+\mathrm{NO}_{2}^{-}\right]$concentration (Pearson $\mathrm{r}=0.656, \mathrm{p}<0.001$; Fig. 1). Concentrations of $\mathrm{NH}_{4}{ }^{+}$in the sediment pore waters were highest in late summer and fall months, and lowest in winter and spring (Fig. 1). The concentration of $\mathrm{NH}_{4}{ }^{+}$in sediment pore waters was uncorrelated with the concentration of $\left[\mathrm{NO}_{3}{ }^{-}+\mathrm{NO}_{2}^{-}\right]$(Pearson $\mathrm{r}=0.02$ ). Sediment DIN in the 0 to $10 \mathrm{~cm}$ core samples was primarily $\mathrm{NH}_{4}{ }^{+}$, (average ratio of $\mathrm{NH}_{4}{ }^{+}:\left[\mathrm{NO}_{3}{ }^{-}+\mathrm{NO}_{2}^{-}\right]=3.1$, while the DIN of the canopy waters was present mostly as $\left[\mathrm{NO}_{3}{ }^{-}+\mathrm{NO}_{2}{ }^{-}\right]$ (average $\mathrm{NH}_{4}{ }^{+}:\left[\mathrm{NO}_{3}{ }^{-}+\mathrm{NO}_{2}^{-}\right]=0.6$ ).

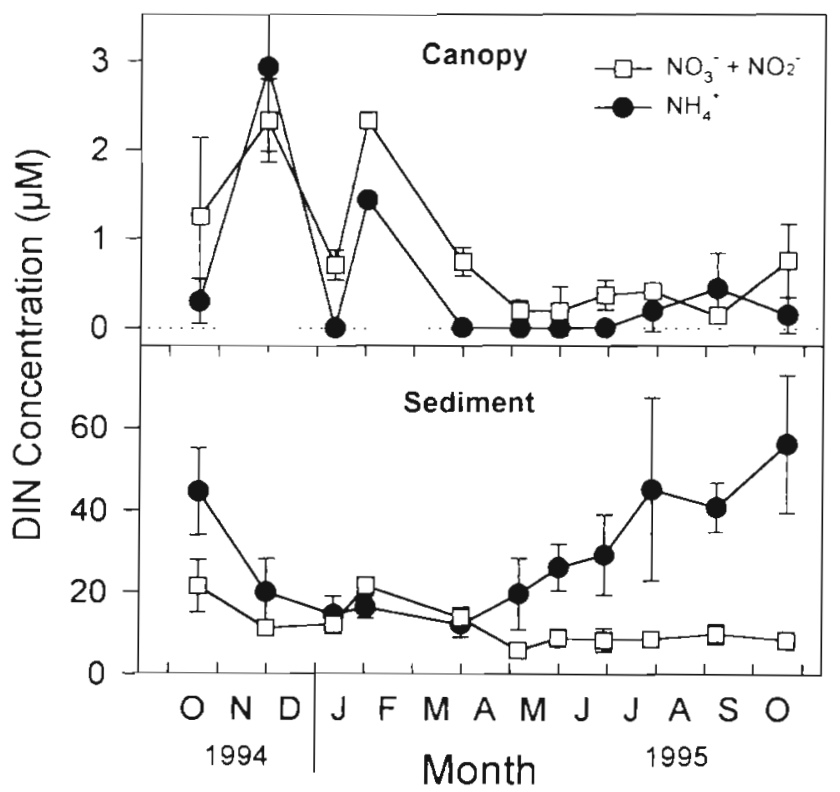

Fig. 1. Dissolved inorganic nitrogen $\left(\mathrm{NH}_{4}{ }^{+},\left[\mathrm{NO}_{3}{ }^{-}+\mathrm{NO}_{2}{ }^{-}\right]\right)$ concentration as a function of date in the shoot canopy ( 3 to 5 $\mathrm{cm}$ from bottom) and sediment pore waters (top $10 \mathrm{~cm}$ ). Error bars represent $\mathrm{SD}$. ( $\mathrm{n}=4$ to 7 )

\section{Biomass}

The annual patterns of the leaf biomass of Cymodocea nodosa and Zostera noltii were similar, with summer highs and mid-winter lows (Fig. 2). The elevated variability for $Z$. noltii at the end of June, 1995, resulted from one unusual quadrat containing only $C$. nodosa biomass. Considerable month-to-month variability existed in the biomass of the root and rhizome tissues of both species. Shoot density also demonstrated no strong relation to the temporal pattern (Fig. 3). Leaf biomass of $Z$. noltii was positively correlated with $C$. nodosa leaf biomass ( $\mathrm{r}=0.72$, $\mathrm{p}<0.001$; Fig. 4), rhizome tissue biomass of the 2 species was uncorrelated $(\mathrm{r}=0.01, \mathrm{p} \gg 0.20)$, while root biomass of $C$. nodosa and $Z$. noltii was negatively correlated $(r=-0.36 ; p<$ $0.05)$

\section{GS activity}

GS activities of Cymodocea nodosa leaves remained low from October through March, after which they increased to maximum values in late June (Fig. 5). Root GS activity was very low compared to leaves of C. nodosa, and with the exception of a late July measurement, was constant. Measurements of GS activity of Zostera noltii leaves showed generally less variability across the annual study, and had one peak in February (Fig. 5). Z. noltii root GS activity varied over the course of the year, although the time of the maximal values was not clear. 


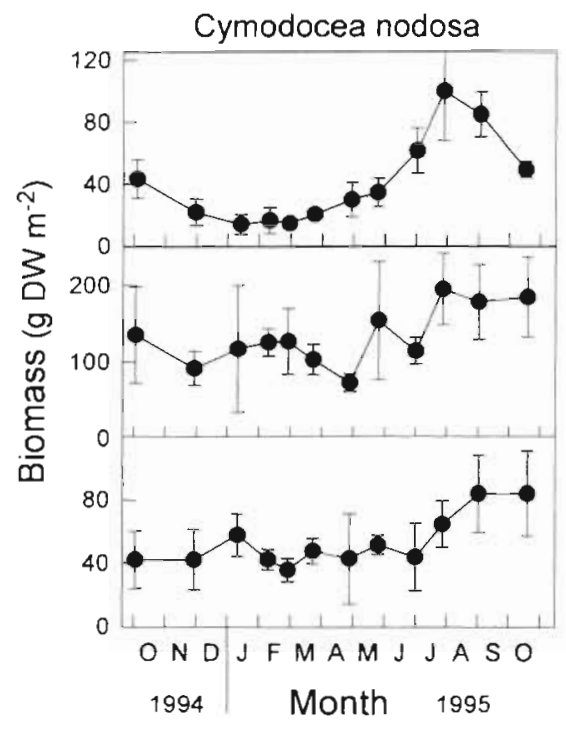

$\mathrm{N}$ contents and demands

Rates of leaf tissue production of both Cymodocea nodosa and Zostera noltii increased from winterspring lows beginning in late April and peaking late in June (Fig. 6). $N$ levels of $C$. nodosa leaves remained high until growth rates increased sharply in May, and $\mathrm{N}$ levels declined to minimum values by August. The $\mathrm{N}$ content of roots and rhizomes of $C$. nodosa increased to May-June highs. The period during which the rhizome and root tissues exhibited the sharpest declines in $N$ content coincided with that for the leaves. $\mathcal{Z}$. noltii leaves exhibited a late-November peak in $N$ content that did not coincide with the rapid increase in growth rate. Leaf $\mathrm{N}$ content declined gradually to the year's lowest $N$ levels by July and remained low through October. The $N$ content of the rhizomes of $Z$. noltii peaked in February and declined to minimal levels by

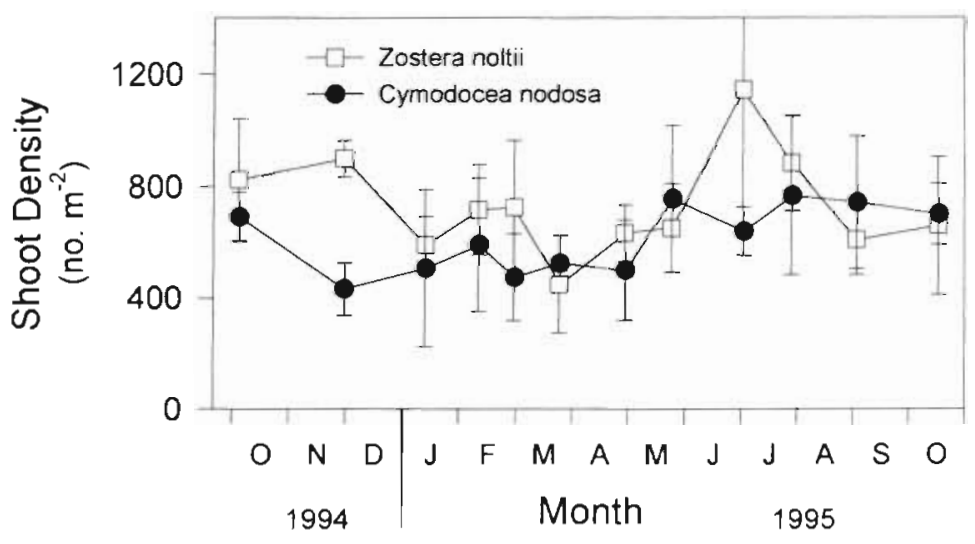

Fig. 3. Cymodocea nodosa and Zostera noltii. Temporal patterns of shoot density of Cymodocea nodosa and Zostera noltii. Error bars represent SD. ( $\mathrm{n}=3$ quadrats [of $400 \mathrm{~cm}^{2}$ each] for each sample)
June, while the $\mathrm{N}$ content of the roots of $Z$. noltii peaked in April-May. With the exception of $Z$. noltii leaves, all tissues of both species experienced a gradual increase in $N$ content coinciding with the decline in leaf growth rate at the end of July (Fig. 6).

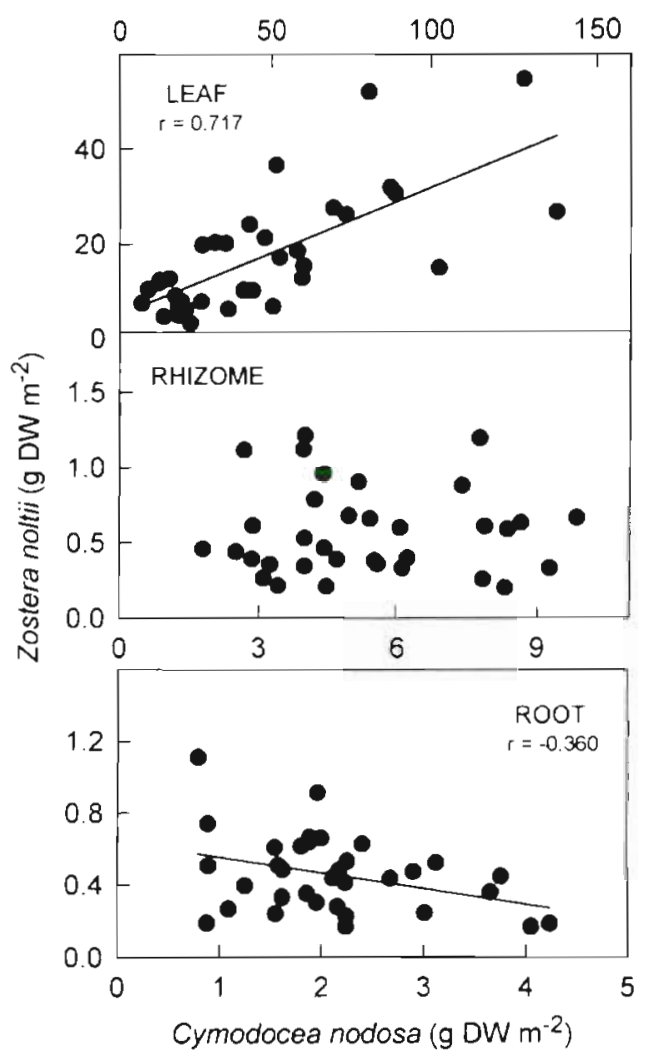

Fig. 4. Cymodocea nodosa and Zostera noltii. Correlations between biomass of tissues. Between-species correlations for both leaf and root biomass are significant ( $p_{\text {leat }}<0.001, p_{\text {root }}<0.05$ ) 
Fig. 5. Cymodocea nodosa and Zostera noltii. Glutamine synthetase activities of shoot and root tissues. Error bars represent $\mathrm{SD}$. ( $\mathrm{n}=5$ for each sample)
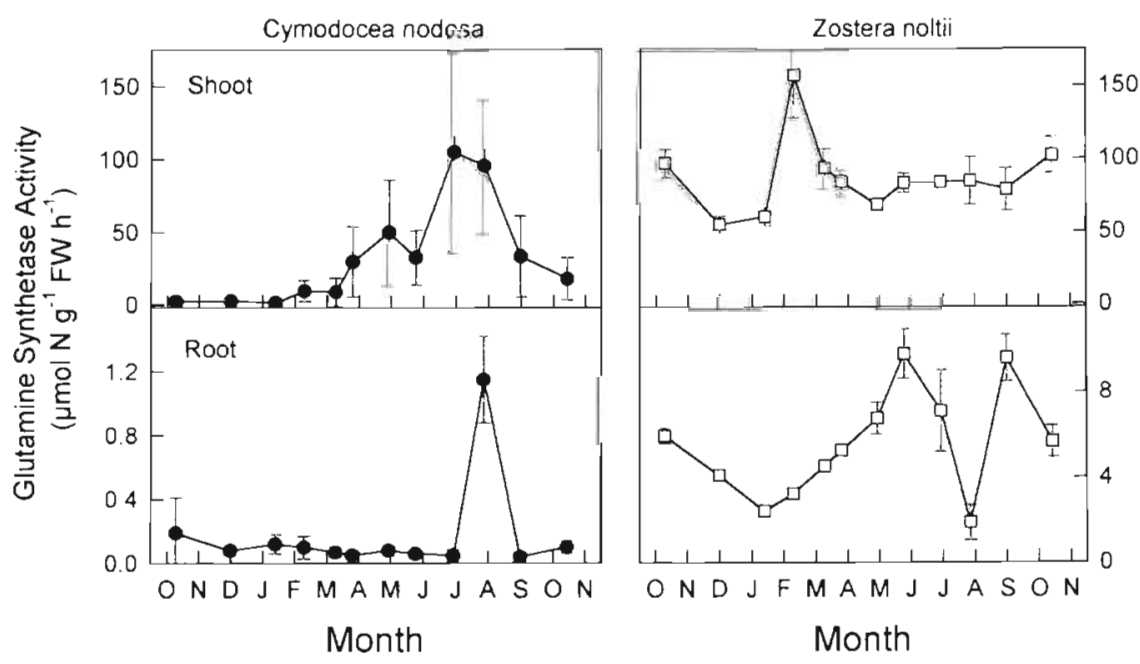

DISCUSSION

Over the course of this study, the pattern of $\mathrm{N}$ required to support the measured growth of existing Cymodocea nodosa leaves was similar to that for Zostera noltii, with a peak in late July (Fig. 7). The peaks for both species corresponded generally with late June peaks in the [leaf + root] NAP calculated for $C$. nodosa and $Z$. noltii. The patterns of [leaf + root] NAP differed between the 2 species across the study. $Z$. noltii had 2 minor peaks (February, June), and exhibited less relative variability in [root + leaf] NAP over the course of the year-long study than did $C$. nodosa. The [leaf + root] NAP for $C$. nodosa peaked sharply in late June to early July. Of the 2 peaks of $Z$. noltii lleaf + root] NAP, that in early February resulted mostly from high GS activity (Fig. 5), while the late July peak was driven primarily by elevated leaf biomass (Fig. 2). Z. noltii NAP, integrated over 12 mo, accounted for $43 \%$ of the NAP totaled for both species.

$\mathrm{N}$ stocks represented by Cymodocea nodosa and Zostera noltii leaves followed sinusoidal temporal patterns (Fig. 8); both were driven primarily by fluctuations in biomass. Total N present in C. nodosa roots and rhizomes lacked apparent temporal variability. The first peak in $Z$. noltii [leaf +root] NAP (early February; Fig. 7) coincided with a peak in rhizome $N$ stocks. The $N$ stock in $Z$. noltii roots also shows a trend with a peak in summer. Within the meadow, the patterns of plant $\mathrm{N}$ stock (all tissues, $C$. nodosa $+Z$. noltii) appeared similar to that for sediment DIN levels, though the cycles were out of phase, with the $\mathrm{N}$ stock minima and maxima preceding by 1 to 2 mo the lows and highs of sediment DIN (Fig. 9).
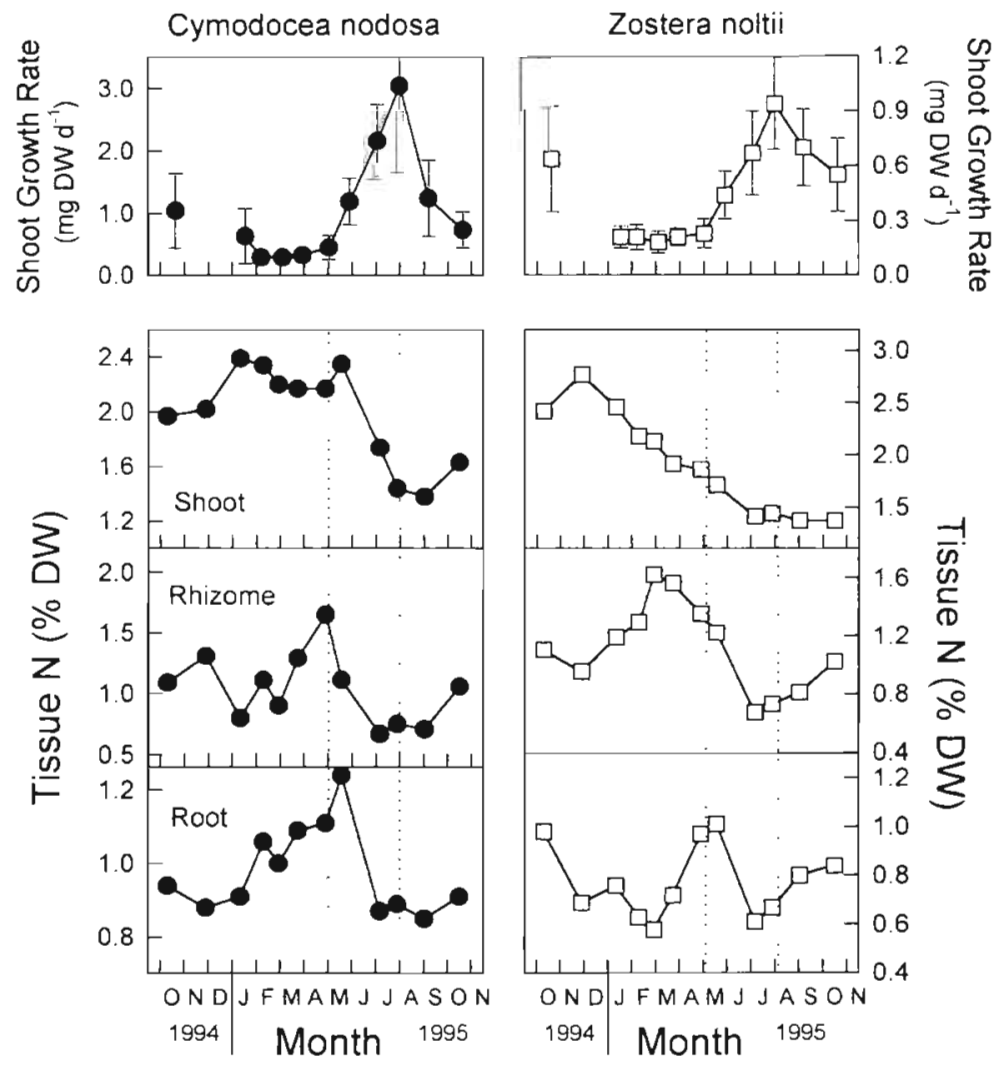
tents of shoot, rhizome, and root tissues. Dotted line indicates point at which leaf growth rates began accelerating and decelerating. Error bars on growth rate data represent SD. Tissue from all 3 quadrats was combined for $N$ content analysis. ( $n_{\text {avg }}$ for growth rate measurements is 16 and 14 for C. nodosa and $Z$. noltii, respectively)
Fig. 6. Cymodocea nodosa and Zostera noltii. Leaf growth rates, and N con- 


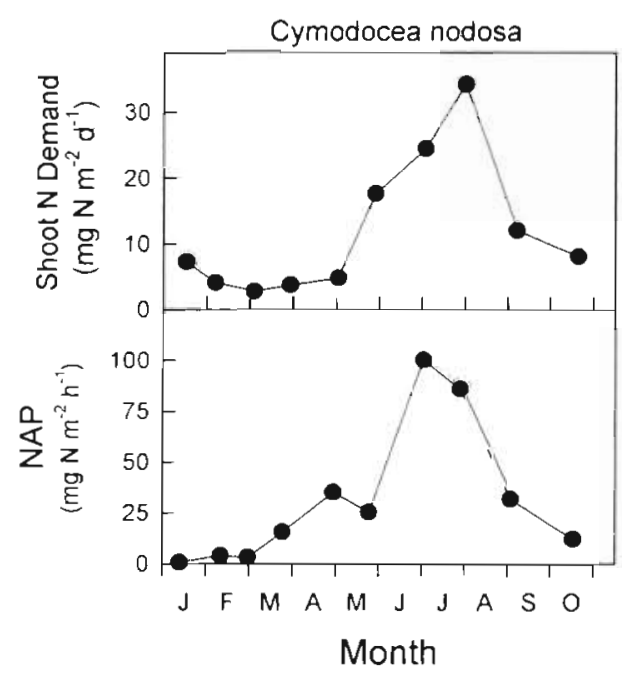

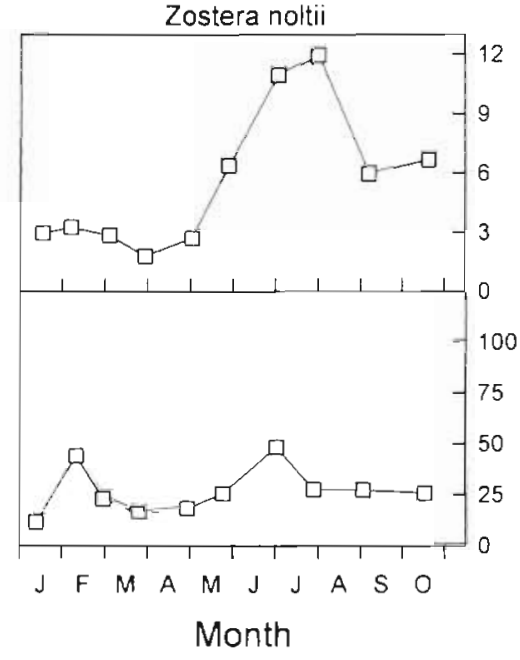

Fig. 7. Cymodocea nodosa and Zostera noltii. Comparison between $\mathrm{N}$ required to support production by existing shoots ( $N$ demand) and potential supply rate (NAP) for [leaf + root tissue] seagrasses employed different physiological strategies to attain similar late-summer production maxima. Strong differences in $\mathrm{N}$ assimilation, gauged by GS activity, existed both between species and between tissues within a species. While most $N$ assimilation by leaves of $C$. nodosa occurred during a short period in summer (May to August), Z. noltii shoots maintained GS activities at relatively constant levels, showing one smaller peak during February when ambient DIN concentrations were highest. While GS activities in $C$. nodosa roots remained very low and relatively constant, those of $Z$. noltii were much higher and showed considerable temporal variability. Additionally, GS activities in leaf tissue were greater than those of root tissue (see also Kraemer \& Mazzella 1996).

These tissue- and species-specific differences in GS activities translated into different annual patterns of [root + leaf] NAP. While NAP of Zostera noltii remained relatively constant over the course of the study (Fig 7), that for Cymodocea nodosa varied greatly. This difference in NAP between the 2 species was a function of differences in both GS activity and biomass. Additionally, the average NAP of $Z$. noltii leaf and root tissues was $43 \%$ of the total for both species; though a smaller seagrass, $Z$. noltii cannot be disregarded when evaluating the ecological roles of the primary producers in this system.

The $\mathrm{N}$ required to sustain measured leaf growth and the potential rates of supply of N (NAP) were calculated independently of each other. The general patterns of these derived quantities were temporally coincident for both species. The early February maximum in the Zostera noltii leaf GS activity and NAP coincided with peaks

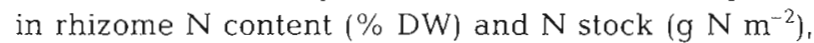
not unexpected given the slow growth rate and the storage function of rhizome tissue. This early-Febru-
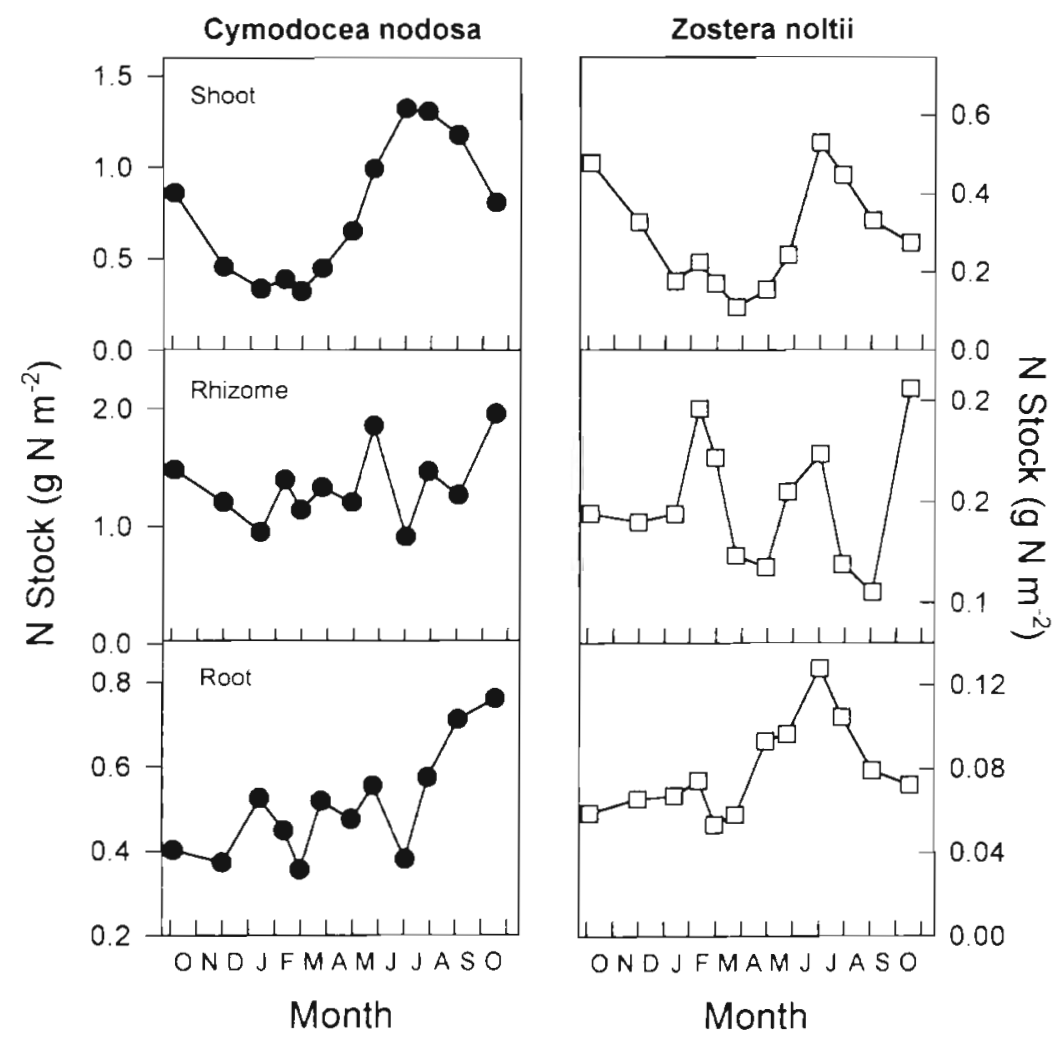

Fig. 8. Cymodocea nodosa and Zostera noltii. N stocks present in shoot, rhizome, and root tissues 
ary peak in NAP also coincided with a period of elevated DIN concentration in the seagrass canopy. The coincidence between canopy $\mathrm{N}$ concentration and NAP did not occur with Cymodocea nodosa, for which the NAP peak was in summer. The $\mathrm{N}$ demands estimated here are underestimates; the $N$ required for the production of new shoots and subterranean tissues are not considered. However, estimated demands are probably not too far from actual, at least for Cymodocea; leaf turnover rate averages 25 times that for the rhizome (Duarte 1991), and plants consist of many ( 7 to $11+$ ) mature shoots (Kraemer unpubl. data, Terrados et al. 1997).

The tissue $N$ dynamics of Zostera noltii clearly differed from those of Cymodocea nodosa, in spite of the fact that both experienced similar environments. The coupling between the external environment and the growth of seagrasses is to some degree species-specific (Marbà et al. 1996). The strength of the coupling should, logically, be strongest in the species with reduced storage capacity and reduced integration of modules along the rhizome. As pointed out earlier, $Z$. noltii allocates proportionately less biomass to storage (rhizome) tissue (Kraemer \& Mazzella 1996). Additionally, modules of $C$. nodosa may be the more highly integrated of the 2 species. The $\mathrm{N}$ content of $C$. nodosa leaf, rhizome, and root tissues remained high until rapid growth commenced, as expected if $\mathrm{N}$ was resorbed and translocated from senescent tissues (Borum et al. 1989, Stapel \& Hemminga 1997). N content in $Z$. noltii leaf and rhizome tissues decreased as water column DIN concentrations decreased, several months prior to the start of rapid growth. This suggests reduced integration among modules, with the loss of conservable tissue $\mathrm{N}$ as senescent tissues were shed. These differences in the acquisition, storage and utilization of tissue $N$, due in part to interspecific differences in integration among clonal modules, may help explain the coexistence of these 2 seagrasses.

Leaf, rhizome, and root tissues generally displayed different patterns of $\mathrm{N}$ accumulation and depletion. The $\mathrm{N}$ content of leaves reached maximum values first (December-January), and there was a progressive delay in the attainment of peak $\mathrm{N}$ contents for rhizome and root tissues; the peaks in rhizome $\mathrm{N}$ content were reached 3 and 4 mo after that of the leaves (Zostera noltii, Cymodocea nodosa, respectively), while the delay was 4.5 and 6 mo for roots (C. nodosa, Z. noltii, respectively). This delay indicates that assimilated $N$ is allocated first to leaves, possibly enabling an increase in the biomass-specific efficiency of $\mathrm{C}$ fixation (e.g. Takano \& Tsunoda 1971). This is apparently followed by the rhizome storage of excess $N$ (that beyond immediate needs to support growth), and finally allocation to root tissues. $Z$. noltii required months to replenish internal $N$ stocks, much more than the week predicted for the congener Zostera marina (Zimmerman et al. 1987). The difference in the patterns of $N$ assimilation and content among tissues and between species argues for the use of a relatively fine-scaled sampling regime; the overall pattern and the periods of rapid change were not evident when samples were collected at 2.5 mo intervals at the same site (Pirc \& Wollenweber 1989).

Leaves may have stored assimilated $\mathrm{N}$ when canopy DIN concentrations were high and growth rate low, and supported growth during periods of high demand; $\mathrm{N}$ contents of Cymodocea nodosa leaves dropped sharply during May, when leaf (and presumably subterranean tissue) growth rates increased from lowest levels (Buia et al. 1991, Cancemi 1991, this study). If photosynthetic potential in seagrasses is related to leaf $\mathrm{N}$ content as in other angiosperms (e.g. Takano \& Tsunoda 1971), the decline in growth rate that began in July-August may derive at least in part from a limitation of productive potential; light was still abundant and DIN concentrations in sediments and canopy waters were, if anything, increasing during this period. Additionally, the growth rate of $C$. nodosa began to decline when leaf $N$ content had decreased to ca $1.4 \%$, below the average value for this species (Duarte 1990).

The similarity in the patterns of the leaf biomass of Zostera noltii and Cymodocea nodosa suggests the existence of a controlling factor(s) common to both species. The environmental functions that exert proximate control over growth include temperature, irradiance, and the supply of inorganic nutrients. Data from this temperate Italian site, as well as results from another study off the coast of Spain showed a stronger correlation between leaf growth rate and temperature than between growth and irradiance (Marbà et al. 1996, Kraemer unpubl. data); when light intensities are satu- 
rating (e.g. spring) growth rates may be limited by the temperature-dependence of metabolism. The negative correlation between the root biomass of the 2 seagrasses was puzzling in view of the positive correlation between shoot biomass and the lack of a relationship between rhizome biomass. This could signal a shift in the $\mathrm{N}$ pool on which $Z$. noltii relies as competition with $C$. nodosa increases.

Local factors are also important in controlling the growth dynamics of seagrasses (Alcoverro et al. 1995). While Cymodocea nodosa collected at the Ischia site showed large (1.5 to 2.5-times) variations in tissue $\mathrm{N}$ content (this study), virtually no variation in tissue $\mathrm{N}$ content was reported in another Spanish study (Pérez \& Romero 1994). Additionally, Pérez \& Romero (1994) reported lower leaf growth rates and broader summer peaks in production than those measured here and elsewhere (Buia et al. 1991). These differences probably derive from differences in the nutrient environment (e.g. river input at the Spanish site, open sea in the present study); while strong patterns in sediment and canopy DIN concentration were observed in the present study, no variation was discernible in either parameter measured by Pérez \& Romero (1994).

The concentrations of $\mathrm{NH}_{4}{ }^{+}$and $\left[\mathrm{NO}_{3}{ }^{-}+\mathrm{NO}_{2}{ }^{-}\right]$in the leaf canopy of this nearshore site followed similar patterns during the study, possibly reflecting similar local cycles of production and consumption. This was not true for sediment pore waters, in which the concentrations of $\mathrm{NH}_{4}{ }^{+}$and $\left[\mathrm{NO}_{3}{ }^{-}+\mathrm{NO}_{2}{ }^{-}\right]$differed. This dissimilarity suggests that the concentrations of the 2 pools of DIN were governed by different processes. The loss functions for $\mathrm{NH}_{4}{ }^{+}$and $\left[\mathrm{NO}_{3}{ }^{-}+\mathrm{NO}_{2}{ }^{-}\right]$(diffusion out of sediments, plant uptake, bacterial conversion) are unknown at this site. However, some sediment DIN is undoubtedly lost through infaunal irrigation and diffusion into the water column (Reay \& Gallagher 1993) where it is available for uptake by seagrass leaves and epiphytes; average concentrations of $\left[\mathrm{NO}_{3}{ }^{-}+\mathrm{NO}_{2}^{-}\right]$in the upper $2 \mathrm{~cm}$ of the sediment and in the canopy water were significantly correlated over the course of the study ( $r=0.76, p=0.017$; data not shown), in agreement with a prior study at a nearby $(3 \mathrm{~km})$ beach (Liebezeit \& Velimirov 1984). Fourqurean et al. (1992) suggested that high porewater nutrient concentrations may derive from, rather than cause, high seagrass standing crop. This idea is supported by the 1 to 2 mo lag between the cycles of plant $N$ stocks and sediment DIN observed in the present study. The lag presumably reflects the period between (1) the deposition of abscised leaves and their attached epibionts, and senescence of subterranean tissue in the sediment matrix, and (2) the appearance of recycled $\mathrm{N}$

Nutrient levels in the environment can mediate competitive interactions among seaweeds (Forqurean et al.
1995). When nutrients are no longer limiting, the grounds for competition may shift to light, with favor going towards those species with greater potential for photosynthetic production relative to maintenance costs. Under these conditions, Zostera noltii may have a competitive advantage over Cymodocea nodosa; shoots of $Z$. noltii constituted 26 to $52 \%$ ( $\mathrm{avg}=36 \%$ ) of total biomass during this study, shoot biomass ranged from only 7 to $28 \%(\mathrm{avg}=17 \%$ ) of the total C. nodosa biomass. At sites characterized by anthropogenic input of excess nutrients and reduced water column transparency, $Z$. noltii may over time replace $C$. nodosa, as Halodule wrightii replaced Thalassia testudinum at experimentally fertilized sites (Forqurean et al. 1995).

While caution must be exercised in generalizing to longer time scales since the data presented here cover only $12 \mathrm{mo}$, similarities exist between this study and others (e.g. Pérez-Lloréns \& Niell 1993, Pérez \& Romero 1994). The results of this study, together with those of others (e.g. Duarte 1991, Marbá et al. 1996), highlight the diversity among seagrasses in structure, physiology, and growth dynamics. The heterogeneity within this group of marine angiosperms is not surprising, given the wide range of environments exploited by seagrasses and their disparate evolutionary histories (Larkum \& den Hartog 1989). The existence of this heterogeneity and others (i.e. degree of clonal integration) requires that different seagrasses experiencing the same abiotic environment be considered separately when evaluating their respective ecological roles.

\section{LITERATURE CITED}

Alcoverro T, Duarte CM, Romero J (1995) Annual growth dynamics of Pasidonia oceanica: contribution of largescale versus local factors to seasonality. Mar Ecol Prog Ser $120: 203-210$

Alcoverro T, Duarte CM, Romero J (1997) The influence of herbivores on Posidonia oceanica epiphytes. Aquat Bot 56: 93-104

Borum J, Murray L, Kemp WM (1989) Aspects of nitrogen acquisition and conservation in eelgrass plants. Aquat Bot 35:289-300

Buia MC, Marzocchi M (1995) Dinamica dei sistemi a Cymodocea nodosa, Zostera marina e Zostera noltii nel Mediterraneo. G Bot Ital 129:319-336

Buia MC, Cancemi G, Procaccini G, Mazzella L (1991) Germination and growth of Cymodocea nodosa in different populations. Oebalia Suppl XVII: 275-282

Caffrey IM (1995) Spatial and seasonal patterns in sediment nitrogen remineralization and ammonium concentrations in San Francisco Bay, California. Estuaries 18:219-233

Cancemi G (1991) Fenologia e produzione primaria di Cymodocea nodosa (Ucria) Aschers. In un prato superficiale dell' Isola d'Ischia (Golfo di Napoli). Thesis, Università di Napoli

den Hartog C (1970) The seagrasses of the world. North-Holland, Amsterdam 
Duarte CM (1990) Seagrass nutrient content. Mar Ecol Prog Ser 67:201-207

Duarte CM (1991) Allometric scaling of seagrass form and productivity. Mar Ecol Prog Ser 77:289-300

Fourqurean JW, Zieman JC, Powell GVN (1992) Relationships between porewater nutrients and seagrasses in a subtropical carbonate environment. Mar Biol 114:57-65

Fourqurean JW, Powell GVN, Kenworthy WJ, Zieman JC (1995) The effects of long-term manipulation of nutrient supply on competition between the seagrasses Thalassia testudinum and Halodule wrightii in Florida Bay. Oikos $72: 349-358$

Harrison PG, Mann KH (1975) Chemical changes during the seasonal cycle of growth and decay of eelgrass (Zostera marina) on the Atlantic coast of Canada. Can J Fish Res 32:615-621

Hemminga MA, Harrison PG, vanLent F (1991) The balance of nutrient losses and gains in seagrass meadows. Mar Ecol Prog Ser 71:85-96

Hemminga MA, Koutstaal BP, van Soelen J, Merks ACA (1994) The nitrogen supply to intertidal eelgrass (Zostera marina). Mar Biol 118:223-227

Jones MN (1984) Nitrate reduction by shaking with cadmium - alternative to cadmium columns. Water Res 18: $643-646$

Kraemer GP, Mazzella L (1996) Nitrogen assimilation and growth dynamics of the Mediterranean seagrasses Posidonia aceanica, Cymodocea nodosa, and Zostera noltii. Proc Rottnest Island Intl Seagrass Symp, Perth, p 181-190

Kraemer GP, Mazzella L, Alberte RS (1997) Nitrogen assimilation and partitioning in the Mediterranean seagrass Posidonia oceanica. PSZN I: Mar Ecol 18:175-187

Larkum AWD, den Hartog C (1989) Evolution and biogeography of seagrasses. In: Larkum AWD, McComb AJ, Shepherd SA (eds) Biology of seagrasses. Elsevier, New York, p $112-156$

Lea PJ (1993) Nitrogen metabolism. In: Lea PJ, Leegood RC (eds) Plant biochemistry and molecular biology. J Wiley and Sons, NewYork

Liddicoat MI, Tibbitts S, Butler EI (1974) The determination of ammonia in seawater. Limnol Oceanogr 20:131-132

Liebezeit G, Velimirov B (1984) Distribution of inorganic and organic nutrients in a sandy beach at Ischia, Bay of Naples. Oceanis 10:437-447

Marbà N, Cebrian J, Enriquez S, Duarte CM (1996) Growth

Editorial responsibility: Gordon Thayer (Contributing

Editor), Beaufort, North Carolina, USA patterns of Western Mediterranean seagrasses: speciesspecific responses to seasonal forcing. Mar Ecol Prog Ser 133:203-215

Pedersen MF, Borum J (1992) Nitrogen dynamics of eelgrass Zostera marina during a late summer period of high growth and low nutrient availability. Mar Ecol Prog Ser 80: $65-73$

Pérez M, Romero J (1994) Growth dynamics, production, and nutrient status of the seagrass Cymodocea nodosa in a Mediterranean semi-estuarine environment. PSZN I: Mar Ecol 15:51-64

Pérez-Lloréns JL, Neill FX (1993) Seasonal dynamics of biomass and nutrient content in the intertidal seagrass Zostera noltii Hornem. from Palmones River estuary, Spain. Aquat Bot 46:49-66

Pirc H, Wollenweber B (1989) Seasonal changes in nitrogen, free amino acids, and $\mathrm{C} / \mathrm{N}$ ratio in Mediterranean seagrasses. PSZN I: Mar Ecol 9:167-179

Pregnall AM, Smith RD, Alberte RS (1987) Glutamine synthetase activity and free amino acid pools of eelgrass (Zostera marina) roots. J Exp Mar Biol Ecol 106:211-228

Scotto di Carlo B, Tomas CR, Ianora A, Marino D, Mazzzocchi MG, Modigh M, Montressor M, Petrillo L, Ribera d'Alcala $M$, Saggiomo $V$, Zingone A (1985) Uno studio integrato dell'ecosystema pelagico costiero del Golfo di Napoli. Nova Thalassia 7:99-128

Stapel J, Hemminga MA (1997) Nutrient resorption from seagrass leaves. Mar Biol 128:197-206

Takano Y, Tsunoda S (1971) Curvilinear regression of the leaf photosynthetic rate on leaf nitrogen content among strains of Oryza species. Jpn J Breed 21:69-76

Terrados J, Duarte CM. Kenworthy WJ (1997) ls the apical growth of Cymodocea nodosa dependent on clonal integration? Mar Ecol Prog Ser 158:103-110

Vidondo B, Duarte CM (1995) Seasonal growth of Codium bursa, a slow-growing Mediterranean macroalga: in situ experimental evidence of nutrient limitation. Mar Ecol Prog Ser 123:185-191

Zieman JC (1974) Methods for the study of the growth and production of turtle grass Thalassia testudinum. Aquaculture $4: 139-143$

Zimmerman RC, Smith RD, Alberte RS (1987) Is growth of eelgrass nitrogen limited? A numerical simulation of the effects of light and temperature on the growth dynamics of Zostera manina. Mar Ecol Prog Ser 41:167-1176

Submitted: November 15, 1997; Accepted: November 2, 1998 Proofs received from author(s): June 9, 1999 